\title{
The Effect of Estrogen in the Elimination of Sexual Odor And on Growth and Carcass Characteristics in Boars
}

\author{
G. Rosado-Carbó, C. M. Berrocal, J. D. Rivera-Anaya, \\ L. A. Lefebre, and I. Carlo'
}

\section{INTRODUCTION}

Estrogenic substances have been used in different animal species for promoting growth gains with various degrees of success $(5,9,1) .{ }^{2}$ However, little investigation has been conducted on their use for the elimination of sexual odor in boars $(3,10)$. Since it is an accepted fact that boars gain weight faster than barrows and gilts, the use of a drug to eliminate castration, and the objectionable odor of boar's pork while increasing its palatability will prove beneficial from an economical standpoint.

It is the purpose of this paper to report the results and observations on the use of diethylstilbestrol implants ${ }^{3}$ and injections of ECP for the elimination of sexual odor in boar's pork. Preliminary observations were reported in a Research Note published in 1963 (7).

\section{MATERIALS AND METHODS}

In an experiment conducted at the Lajas Agricultural Experiment Substation, three 56-day-old weanling male pigs were selected from each of 28 litters and randomized in three experimental groups.

A total of 82 boars was used; each of 28 animals in one group was treated with a $96 \mathrm{mg}$. of diethylstilbestrol (DES) implant; each of another group of 26 boars was injected with $9.6 \mathrm{mg}$. of ECP; and a third group of 28 boars served as controls.

The jowl was used as the site for the DES implantations and the ham for the ECP injections. The dosage was always divided and applied at two different sites.

The boars used were $3 / 4$ Duroc $\times 1 / 4$ English Large Black Landrace from

1 Veterinarian, Assistant Bacteriologist, Veterinarian, Research Assistant, and Animal Husbandman, respectively, Agricultural Experiment Station, Mayagüez Campus, University of Puerto Rico, Rfo Piedras, P.R.

2 Italic numbers in parentheses refer to Literature Cited, pp. 336-7.

s "Stimplants", Pfizer Corporation.

4 ECP, commercial name for Estradiol Cyclopentyl Propionate, Upjohn Corp. Trade names are used in this publication solely for the purpose of providing specific information. Mention of a trade name does not constitute a guarantee, warranty, or endorsement by the Agricultural Experiment Station indicating superiority to other similar products not mentioned. 
a line developed at the Agricultural Experiment Station, University of Puerto Rico (2). The animals were placed in individual pens and fed freechoice a concentrate ration mixed at the Substation. The boars were weighed at the start and at the end of the experimental period of 98 days. Feed consumption was recorded to determine rate of gain and feed efficiency.

The treated groups were slaughtered within 2 weeks after the completion of the period. Records were kept on carcass weight and backfat thickness. The carcasses were chilled for 24 hours before cutting. Loin-eye area measurements were recorded and filed for further comparisons. Samples of fat and muscle from the ham were tested organoleptically, and portions of fat and liver were used in the determination of residual estrogen (6).

For flavor determination (4), salted meat samples of $3 / 4$-inch thickness were placed in an oven for 1 hour 50 minutes at a temperature of $325^{\circ} \mathrm{F}$. The samples were then cut into small pieces, placed under a red light and exposed to a taste panel. The following scale was used for the taste scores:

$\begin{array}{lr}\text { Very acceptable } & +2 \\ \text { Acceptable } & +1 \\ \text { Questionable } & 0 \\ \text { Slightly unacceptable } & -1 \\ \text { Not acceptable } & -2\end{array}$

Water was offered to the tasters between pork samples to eliminate the carry-over effect.

Samples of pork and fat were placed in separate covered pans with part of the meat juice which is produced during cooking for odor determination. The above scoring scale was also used for odor appreciation.

A modification of the Stob technique developed by Preston et al. (6) was used for residual estrogen determinations. A group of five intact, immature female mice was fed a mixture of fat and liver from each boar in both treatments for 7 days. The diet consisted of a mixture containing 80 percent of dried ground liver and backfat (2.33:1) from slaughtered animals which had been either injected with ECP or implanted with DES and 20 percent of a basal diet consisting of vitamin-and-fat-free casein and a mice vitamin mixture (9:1). Separate control groups of mice were fed a ration of dried ground liver and dried ground backfat (4:1) from animals that had received no estrogen.

To establish a standard curve for comparisons, modifications of the diet used in the control groups were fed to an additional six groups of five mice each. These diets contained measured amounts of DES in proportions of $0.00 ; 0.005 ; 0.010 ; 0.020 ; 0.030$, and $0.050 \mu \mathrm{g}$. per gram of feed.

All mice were sacrificed and their uteri removed and fixed in Bouin's solution for 24 hours, dried and weighed in a semimicro balance. The 
average weight of the uteri from the mice fed tissues from the boars that received estrogen was compared to the average uterine weight of the control mice. The difference in average uterine weight of these animals was used as criterion of estrogen accumulation in the tissue. The estimated amount of estrogen present in the tissue was determined by comparing the mean uterine weight thus obtained to the standard curve.

\section{RESULTS AND OBSERVATIONS}

Flavor and Odor

Table 1 shows results of the organoleptic comparisons between the control, the implanted, and the injected groups. No significant difference was

TABLE 1.-Panel organoleptic results on pork from boars trealed with DES and ECP, 1966-67

\begin{tabular}{|c|c|c|c|}
\hline Group & Number of samples & Average & Range \\
\hline \multicolumn{4}{|c|}{$A-$ Flavor $^{1}$} \\
\hline $\begin{array}{l}\text { Injected } \\
\text { Implanted } \\
\text { Control }\end{array}$ & $\begin{array}{l}46 \\
56 \\
30\end{array}$ & $\begin{array}{r}0.900 \\
.905 \\
.909\end{array}$ & $\begin{array}{l}+0.300 \text { to }+1.330 \\
+.200 \text { to }+1.500 \\
+.400 \text { to }+1.270\end{array}$ \\
\hline \multicolumn{4}{|c|}{$B-O d o r^{2}$} \\
\hline $\begin{array}{l}\text { Injected } \\
\text { Implanted } \\
\text { Control }\end{array}$ & $\begin{array}{l}67 \\
68 \\
39\end{array}$ & $\begin{array}{r}0.657 \\
.627 \\
.878\end{array}$ & $\begin{array}{l}-0.200 \text { to }+1.120 \\
-.100 \text { to }+1.100 \\
+.300 \text { to }+1.180\end{array}$ \\
\hline
\end{tabular}

1 No significant difference between treatments was determined.

found in flavor and odor between the DES implanted and the ECP injected groups against the control. These results made the comparison between the implanted and the injected groups obviously unnecessary.

\section{ESTROGEN RESIDUE}

The determination of estrogen residues in the mice used for the test showed a mean uterine weight of $35.96 \mathrm{mg}$. for those fed tissues from boars injected with ECP, and $39.17 \mathrm{mg}$. for the group fed tissues from boars implanted with DES (table 2). The average weight for the uteri of the control mice was $22.34 \mathrm{mg}$. There was no significant difference between treatments (table 3).

The standard values or mean weights of uteri of mice fed the control diet with added measured amounts of DES are presented in table 4.

It should be noted that the control, the diet without any added amount 
of diethylstilbestrol, had a higher uterine weight than the $0.005,0.010$ and 0.020 levels.

These results are consistent with the findings of Preston et al., and other authors cited by them $(6)$, where, for unknown and undetermined reasons,

TABLE 2.-Ulerine weights of immature white mice fed tissues from boars treated with DES and ECP, 1966-67

\begin{tabular}{l|c|c|c}
\hline \multirow{2}{*}{ Group } & \multirow{2}{*}{ Mice } & \multicolumn{2}{|c}{ Uterine weight } \\
\cline { 2 - 4 } & & Average & Range \\
\cline { 2 - 4 } & Number & Milligrams & Milligrams \\
Injected & 135 & 35.96 & $8.53-106.00$ \\
Implanted & 140 & 39.17 & $7.53-111.65$ \\
Control & 15 & 22.34 & $13.70-31.50$ \\
\hline
\end{tabular}

TABLE 3.-Analyses of variances for uterine residual estrogen in mice fed tissues from boars treated with DES and ECP, 1966-67

\begin{tabular}{l|c|c|c|c}
\hline Source of variation & $\begin{array}{c}\text { Degrees of } \\
\text { freedom }\end{array}$ & Sum of squares & Mean squares & $F$ \\
\cline { 1 - 2 } Total & 57 & 0.0371 & & \\
Treatments & 2 & .0008 & 0.0004 & $0.60^{1}$ \\
Error & 55 & .0363 & .0006 & \\
\hline
\end{tabular}

1 Not significant.

TABLE 4.-Standard values of ulerine weighls of immalure mice fed measured amounts of $D E S / g$. of feed, $1966-67$

\begin{tabular}{c|c|c}
\hline DES added to dry tissue & Mice & Average uterine weight \\
\hline Milligrams/gram & Number & Milligrams \\
0.000 & 5 & 23.90 \\
.005 & 5 & 9.30 \\
.010 & 5 & 19.90 \\
.020 & 5 & 22.10 \\
.030 & 5 & 25.60 \\
.050 & 5 & 35.90 \\
\hline
\end{tabular}

some of the controls had heavier uteri than mice fed measured amounts of DES in the ration.

Table 5 presents values for estrogen deposition in tissues from treated boars. A residual content of $.0075 \mu \mathrm{g}$. of ECP and of $.0082 \mu \mathrm{g}$. of DES per g. of tissue was determined.

The U. S. Dispensatory as cited by Stob et al. (9) establishes $1 \mathrm{mg}$. of DES per day as a typical therapeutic dose for man. 
According to the concentration observed in the present report, $(0.0082$

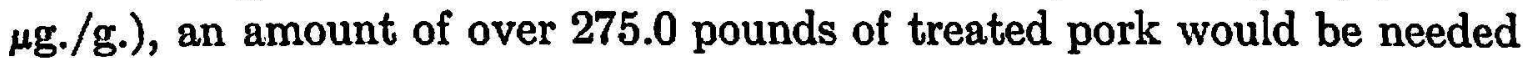
to reach the therapeutic individual dose of $1 \mathrm{mg}$. DES/day.

Since the per capita consumption of pork in Puerto Rico is 37 pounds a year, the amount of estrogen consumed in treated pork does not constitute any health hazard at the indicated levels.

Since the per capita consumption of pork in the U.S.A. is 46 pounds and 63 pounds for the white and nonwhite populations, respectively, the above findings similarly would indicate no health hazard to the consumers of treated pork at the aforementioned estrogen concentrations.

TABLE 5.-Differences in ulerine weights of immature white mice fed tissue from boars treated with DES and ECP as compared to controls, 1966-67

\begin{tabular}{l|c|c|c}
\hline \multirow{2}{*}{ Groups } & Samples & \multicolumn{2}{|c}{ Uterine weight } \\
\cline { 2 - 3 } & & Average & Range \\
\hline & Number & Milligrams & Milligrams \\
Injected & $27(135)^{1}$ & $17.15^{2}$ & -13.81 to +83.66 \\
Implanted & $28(140)$ & $16.76^{3}$ & -14.81 to +89.31 \\
Control & $-(15)$ & 22.34 & +13.70 to +31.50 \\
\hline
\end{tabular}

1 Number in parentheses represents mice examined/treatment.

2 Equivalent to $.0075 \mu \mathrm{g}$. of ECP/g. of tissue.

${ }^{3}$ Equivalent to $.0082 \mu \mathrm{g}$. DES/g. of tissue.

\section{Carcass Quality}

The average weaning weights, rates of gain, and feed efficiency are shown in table 6. Analyses of variance were used to compare thickness of backfat, loin-eye areas, feed efficiency, and rate of gain, among the three groups of boars (table 7). Where the F-value was statistically significant, the Duncan's New Multiple Range Test ( 8 ) was applied to determine statistical significance between the differences.

The nonestrogen-treated boars of the control group were not slaughtered because the undesirable odor of their pork would interfere with the flavorand-odor tests being conducted. In order to make comparisons for loin-eye area and backfat, a set of similar values from barrows was used.

Table 8 shows the average loin-eye area and backfat thickness for the three groups. The loin-eye area measurements were similar for the ECPinjected and the DES-implanted groups; both were greater than the controls. However, this difference was not significant (table 7).

Boars in the DES-implanted group were superior to those of the ECPinjected group and the controls in backfat thickness. The value was highly significant at the level of 1 percent (table 7). In corroboration, the Duncan's Multiple Range Test showed a significant difference at the 1-percent level 
TABLE 6.-Average weaning weight, rale of gain and feed efficiency of DESimplanted, and ECP-injected and control boars, 1966-67

\begin{tabular}{l|c|c|c|c}
\hline \multirow{2}{*}{ Group } & Animals & Weaning weight & \multicolumn{2}{|c}{ Average } \\
\cline { 3 - 5 } & & & Rate of gain? & Feed efficiencyz \\
\cline { 2 - 5 } & Number & $L b$. & $L b$. & $L b$. \\
Injected & 26 & 29.25 & 1.67 & 3.52 \\
Implanted & 28 & 32.82 & 1.66 & 3.65 \\
Control & 28 & 32.07 & 1.58 & 3.69 \\
\hline
\end{tabular}

1 Rate of gain was measured as weight gain per day.

${ }^{2}$ Feed efficiency was measured as pounds of feed needed to gain 1 pound in weight.

TABLE 7.-Analyses of variance for efficiency and carcass traits of boars treated with DES and ECP, 1966-67

\begin{tabular}{|c|c|c|c|c|}
\hline Source of variation & $\begin{array}{l}\text { Degrees of } \\
\text { freedom }\end{array}$ & Sum of squares & Mean squares & $\boldsymbol{F}$ \\
\hline \multicolumn{5}{|c|}{ Back-fat Thickness } \\
\hline $\begin{array}{l}\text { Total } \\
\text { Treatments } \\
\text { Error }\end{array}$ & $\begin{array}{r}79 \\
2 \\
77\end{array}$ & $\begin{array}{l}7.0191 \\
1.2971 \\
5.7220\end{array}$ & $\begin{array}{r}0 . \overline{6486} \\
.0743\end{array}$ & $8.73^{* *}$ \\
\hline \multicolumn{5}{|c|}{ 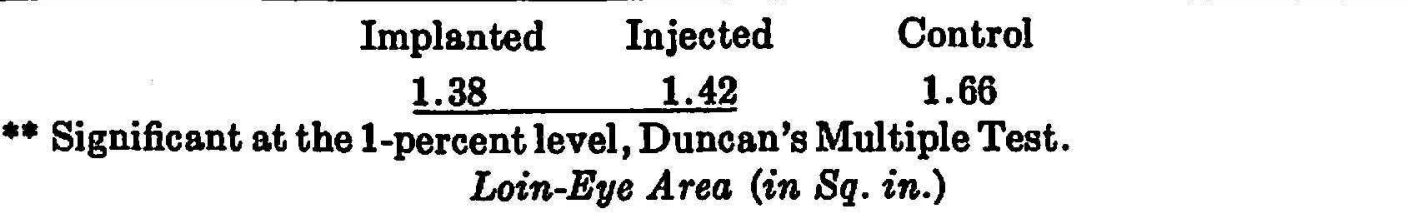 } \\
\hline $\begin{array}{l}\text { Total } \\
\text { Treatments } \\
\text { Error }\end{array}$ & $\begin{array}{r}80 \\
2 \\
78\end{array}$ & $\begin{array}{r}23.7068 \\
1.2590 \\
22.4478\end{array}$ & $\begin{array}{r}-\overline{0295} \\
.2878\end{array}$ & $2.19^{1}$ \\
\hline \multicolumn{5}{|c|}{ Feed Efficiency } \\
\hline $\begin{array}{l}\text { Total } \\
\text { Treatments } \\
\text { Error }\end{array}$ & $\begin{array}{r}72 \\
2 \\
70\end{array}$ & $\begin{array}{r}545,419.8288 \\
2,366.0953 \\
543,053.7335\end{array}$ & $\begin{array}{c}- \\
1,183.0477 \\
7,757.9105\end{array}$ & $.15^{1}$ \\
\hline \multicolumn{5}{|c|}{ Rate of Gain } \\
\hline $\begin{array}{l}\text { Total } \\
\text { Treatments } \\
\text { Error }\end{array}$ & $\begin{array}{r}81 \\
2 \\
79\end{array}$ & $\begin{array}{r}4.7037 \\
.1528 \\
4.5509\end{array}$ & $\begin{array}{r}-\overline{0764} \\
.0576\end{array}$ & $1.33^{1}$ \\
\hline
\end{tabular}

1 Not significant. 
between the injected and the implanted groups when compared with the controls, but no significant difference between the two treated groups (table 7). In interpreting results of the Duncan's Multiple Comparison Test, any two values not underscored by the same line are significantly different, while any two values underscored by the same line are not significantly different.

\section{Rate of Growth and Feed Efficiency}

The average weaning weight was less for the ECP-injected group than for either the DES-implanted or the control groups. However, boars of the

TABLD 8.-Loin-eye area and back fat of ECP-injected, DES-implanted and control boars, 1966-67

\begin{tabular}{c|c|c|c}
\hline \multirow{2}{*}{ Group } & Number of animals & \multicolumn{2}{|c}{ Average } \\
\cline { 3 - 4 } & & Loin-eye area & Back-fat thickness \\
\hline & 26 & Square inches & Inches \\
Injected & 27 & 3.33 & $1.42^{2}$ \\
Implanted & 28 & 3.33 & 1.38 \\
Control & 3.07 & 1.66 \\
\hline
\end{tabular}

1 Represents the average of the measurements taken over the first and last ribs and at the lumbar area.

2 The average of only 25 animals.

ECP-injected group showed a better rate of gain and a better feed efficiency than those of the other two groups.

Findings in this experiment indicate that there is no health hazard for boars from the use of DES or ECP, nor for the consumers of pork from treated boars. The pork from estrogen-treated boars has acceptable flavor and odor. Estrogen-treated boars can be slaughtered without previous castration, an economical advantage to hog farmers and pork packers.

\section{SUMMARY}

An experiment to determine the feasibility of using DES or ECP for the elimination of sexual odor and flavor in pork from boars was conducted at Lajas Agricultural Experiment Substation.

Implantation of $96 \mathrm{mg}$. of DES, or injection of an equivalent dosage of ECP eliminates sexual odor and flavor from boars, enabling the hog farmer to slaughter treated boars without previous castration at weaning time.

Analyses of variance of the loin-eye area, depth of backfat, rate of gain and feed efficiency showed no significant differences when compared to pork 
from castrated animals. Results also demonstrated no significant differences in the organoleptic tests.

The amount of residual estrogen per gram of treated pork determined by this experiment does not represent a public health hazard; it would be necessary to consume over 275 pounds of treated pork to ingest the therapeutic dose of $1 \mathrm{mg}$. of DES per day.

\section{RESUMEN}

En la Subestación Experimental Agrícola de Lajas se efectuó un experimento para determinar la posibilidad de usar dietilestilbestrol (DES) y propionato ciclopentílico de estradiol (ECP) en verracos para eliminar el olor y sabor característico de la carne del cerdo macho.

Un implante de $96 \mathrm{mg}$. de DES, o una dosis equivalente de ECP injectada, elimina estos olores y sabores desagradables. El implante o la inyección se efectuó al destetar los cerditos a los 56 días de edad. Esta práctica permite a los criadores de cerdos sacrificar comercialmente los verracos tratados con estos estrógenos, sin castrar previamente los cerditos al destete.

Los análisis estadísticos para el área del músculo dorsal largo, capa de grasa dorsal, razón de ganancia en peso y eficiencia de conversión no demostraron diferencia significativa. Las pruebas organolépticas tampoco demostraron diferencia significativa al compararse con los testigos.

La cantidad de estrógeno residual por gramo de carne de verraco, determinada en este experimento, no representa peligro alguno para la salud pública, ya que una persona necesitaría consumir 275 libras de carne de cerdo tratada con estrógenos para llegar a ingerir la dosis terapéutica de un miligramo de DES por día.

\section{LITERATURE CITED}

1. Cahill, V. R., Teague, H. S., Kunkle, L. E., Moxon, A. L., and Rutledge, E. A., Measurement and ways of affecting sex-influenced performance of growingfinishing swine, J. Anim. Sc. 19 (4): 1,036-40, 1960.

2. Carlo, I., and Arcelay, C. L., Evaluation of a swine line developed at the Agricultural Experiment Station of the University of Puerto Rico, J. Agr. Univ. P.R. b1 (1): 4-21, 1967.

3. Christian, R. E., and Turk, R. M., Jr., A study of the cause of the sexual odor in the boar, J. Anim. Sc. 16 (4): 1,024-25, 1959.

4. Kramer, A., and Ditman, L. P., A simplified variable test panel method for detecting flavor changes in vegetables treated with pesticide, Food Technology 10: $155-9,1956$.

5. Pearson, A. M., Combs, G. F., Jr., Wallace, H. D., Sheeth, R. B., Stroud, J. W., Shepherd, J. M., and Roger, Marvin, The effects of stilbestrol implants on swine of different sexes, J. Anim. Sc. 11 (2): 251-60, 1952.

6. Preston, R., Cheng, E., Story, C. D., Homeyer, P., Vavls, J., and Burroughs, W., The influence of oral administration of Diethylstilbestrol upon estrogenic residues on the tissue of calf cattle, J. Anim. Sc. 16 (1): 3-12, 1956. 
7. Rosado-Carbó, G., Rivera-Anaya, J. D., Rahman, A. R., Carlo, I., and Berrocal, C. M., Effect of Estrogen in the elimination of sexual odor in boars, J. Agr. Univ. P.R. 47 (3): 217, 1963.

8. Steel, R. G D., and Torie J.H., Principles and Procedures of Statistics, McGrawHill Book Co., New York, N.Y., pp. 107-09, 1960.

9. Stob, M., Andrews, F. N., Zarrow, M. X., The detection of residual hormone in the meat of animals treated with synthetic estrogens, Am.J.Vet. Res. 15: 319-22, 1954.

10. Teague, H. S., Plimpton, R. F., Cahill, V. R., Grifo, A. P., and Kunkle, L. E., Influence of diethylstilbestrol implantation on growth and carcass characteristies of boars, J. Anin. Sc. 28 (2): 332-38, 1964. 